\title{
MENGUKUR KETEPATAN KUALITAS INFORMASI SISTEM TRACER DAN TRACKING JASA KURIR
}

\author{
Sasa Ani Arnomo \\ Universitas Putera Batam, Indonesia.
}

\section{INFORMASI ARTIKEL}

Diterima Redaksi: 5 Januari 2018

Diterbitkan Online: 31 Maret 2018

\section{KATA KUNCI}

Tracer, Trancking, Quality, System, Information

\section{KORESPONDENSI}

E-mail: sasaupb@gmail.com

\begin{abstract}
A B S $\mathbf{S}$ T $\mathbf{R}$ A $\mathbf{C}$ T
With the development of e-commerce, the sale and purchase transaction more and more. The scope of e-commerce is very wide because internet access is spread all over the region. The development of e-commerce users is affecting business in the delivery of goods. To know the goods have been processed for delivery or not the courier service delivery of goods provide trace and tracking system. In this study will examine how the accuracy of the quality of information on trace systems and tracking as a service system that provides convenience to users and customers in knowing where the goods we send or receive. The research variables as the direction of measurement are Interest (importance), Clarity (clarity), Relevance (relevance), usefulness (usefulness). Research method by means of descriptive research that is method used to analyze data by way of describing or describing data that have been collected. The samples taken are batam city people who have or are using the system trace and tracking courier services. The purpose of research to know how the quality of information displayed so as to provide information assessment for the community.
\end{abstract}

\section{Latar Belakang}

Perkembangan teknologi dan sistem informasi saat ini banyak digunakan perusahaan dalam meningkatkan penjualan dan pelayanannya. Banyak perusahaan menggunakan layanan internet dalam melakukan promosi, memberikan informasi mengenai produk, layanan dan lain-lain. Sistem Informasi Trace dan Tracking ini sendiri berguna bagi calon pengguna atau pelanggan untuk memerlukan informasi yang lebih luas tentang pengiriman barang yang telah. Sistem Informasi Trace dan Tracking sangat membantu pengguna atau pelanggan apabila tidak ada waktu luang dalam hal ingin mengetahui sampai mana barang pesanan atau barang yang dikirim melalui http://ejournal.upbatam.ac.id/index.php/cbis penyedia jasa jurir. Adapun sebagai objek penelitian adalah PT JNE. Sistem Informasi Trace dan Tracking ini bisa dilakukan dimanapun pengguna atau pelanggan berada. Dalam mengoperasikanya, Sistem Informasi Trace dan Tracking ini sangatlah mudah, pengguna atau pelanggan hanya memasukan (input) nomor resi yang telah diberikan saat mengirim barang ataupun saat pelanggan memesan barang online dari suatu ecommerce. Setelah itu pengguna atau pelanggan diminta untuk memasukan huruf dan angka (chapta) selanjutnya Sistem Informasi Trace dan Tracking ini akan memberikan informasi kepada pengguna atau pelanggan apakah pengiriman barangnya masih dalam proses (on process) atau sudah tiba 
(delivery) ditempat. Selain Sistem Informasi Trace dan Tracking, Sistem Informasi Website JNE memberikan dan menawarkan layanan dan juga berbagai macam produk apa saja yang ada di dalam Website JNE. Di dalam Website JNE ini juga tersedia layanan hotlink atau layanan bebas pulsa yang berguna untuk calon pengguna atau pelanggan dalam memperoleh informasi lebih tentang produk dan layanan jasa yang akan diberikan oleh PT JNE Expression Across Nation. Dalam meningkatkan layanan jasa dan juga bertujuan untuk memenuhi keinginan pengguna dan pelanggan sistem informasi ini sangat berguna, bagi perusahaan, bank, projek factory, dan perumahan dalam mencari informasi tentang produk perusahaan ini. Dengan ketersedian sistem informasi ini manajemen ingin memberikan lebih dari yang dimau atau diharapkan agar pengguna atau pelanggan menjadi puas.

Dengan melihat perkembangan sistem informasi ini sebuah bisnis akan mengembangkan bisnisnya bukan hanya dalam persaingan dunia bebas tetapi juga dalam dunia website atau e-Bussiness yang merupakan daya tarik tersendiri dalam manajemen untuk melakukan perubahan dan juga mengembangkan bisnis. Selain itu marketing public relation juga dikembangkan baik melalui online maunpun dilaksanakan secara langsung, semakin ditingkatkan maka akan berpengaruh terhadap loyalitas pelanggan [1].

PT JNE Expression Across Nation mencoba bersaing dengan para kompetitornya dalam penentuan biaya yang ekonomis dimana biaya pendistribusian barang yang dikirim berdasarkan jenis barang, berat barang dan tujuan pengiriman [2].

Sistem Informasi Trace dan Tracking juga mempengaruhi cara dan sudut pandang karyawan dalam melaksanakan tugas dan tanggung jawabnya, sebuah pekerjaan akan berjalan baik apabila sudah tersistem dan terstruktur dengan baik. Sebuah bisnis akan dapat berjalan sesuai dengan harapan apabila hubungan antara pelanggan atau pengguna dan perusahaan terjaga dengan baik, dengan saling bertukar informasi tentang kelemahan dan kelebihan sistem informasi dan pelayanan yang diberikan, berguna juga untuk memberikan informasi guna dalam mengembangkan sistem yang sedang berjalan.
Dengan sistem informasi ini di harapkan dapat memberikan informasi yang dibutuhkan calon pengguna atau pelanggan. Pengguna atau pelanggan dapat mengakses Sistem Informasi Trace dan Tracking ini dimana saja dan kapan saja kita mau untuk memperoleh informasi khususnya dalam pengiriman barang. Tidak jarang pengguna atau pelanggan yang diluar Batam atau yang didaerah Batam membuka Sistem Informasi Trace dan Tracking ini yang hanya untuk mencari informasi yang diinginkan oleh pengguna dan pelanggan. Perkembangan informasi dan teknologi ini sangat bermanfaat besar. Sistem Informasi Trace dan Tracking merupakan salah satu dari sekian banyaknya perkembangan informasi dan teknologi yang bisa dimanfaatkan dalam dunia bisnis atau usaha online lainnya, karena penggunaan internet yang sudah mendarah daging dalam perkembangan informasi dan teknologi pada saat ini.

Dengan adanya perkembangan bisnis dan sistem informasi yang secara silmutan dapat mendorong kelincahan, efisiensi, dan kualitas. Kualitas informasi meliputi hal - hal seperti informasi yang akurat, informasi yang bisa dipercaya, informasi yang up to date / terbaru, informasi yang sesuai dengan topik bahasan, informasi yang mudah dimengerti, informasi yang sangat detail, dan informasi yang disajikan dalam format desain yang sesuai [3]. Sebuah perusahaan harus dapat dalam merespon pelanggan dan pengguna dan perubahanperubahan yang terjadi dipasar dengan cepat. Sistem informasi sangat mempengaruhi perubahan daya jual dan daya minat pelanggan. Melebarkan jangkauan dengan menggunakan sistem informasi internet dapat meningkatkan bisnis dalam dunia maya maupun dalam persaingan bisnis yang sesungguhnya, dengan menggunakan internet dalam meningkatkan bisnis merupakan salah satu pilihan dalam peningkatan bisnis.

Dengan menggunakan sistem informasi yang berbasis internet ini kita dapat mengaksesnya dimana saja. PT JNE Expression Across Nation memberikan informasi yang jelas tentang masalah yang dihadapi oleh calon pengguna atau pelanggan khususnya dalam hal pengiriman barang. Tidak hanya itu, pemasaran yang disediakan dalam layanan website secara online adalah pemasaran dalam bidang pelayanan jasa dan juga menjadi pemecah solusi 
yang sedang dihadapi sebuah perusahaan, cafe, public area, bank, dan lain-lain. Dengan menggunakan jaringan internet penguasaan bisnis secara global akan lebih menigkatkan penjualan dan juga akan meningkatkan promosi yang akan menarik minat pelanggan dalam menggunakan jasa pengiriman barang. Website juga dapat menampung keluhan pelanggan atau pengguna tentang pengiriman barang melalui udara, darat maupun laut. Sistem Informasi Trace dan Tracking yang digunakan oleh PT JNE Expression Across Nation juga bermanfaat sebagai interaksi antara pengguna, calon pelanggan dan mitra kerja dalam memperoleh sebuah informasi tentang layanan jasa pengiriman barang dan juga solusi pemecahan masalah tersebut.

Adapun tujuan dari penelitian ini yaitu: (1)Mengukur tingkat kualitas tingkat kepentingan (importance) informasi pada Sistem Trace dan Tracking. (2) Mengukur tingkat kualitas tingkat kejelasan (clarity) informasi pada Sistem Trace dan Tracking. (3) Mengukur tingkat kualitas tingkat relevan (relevance) informasi pada Sistem Trace dan Tracking. (4) Mengukur tingkat kualitas tingkat kegunaan (usefulness) informasi pada Sistem Trace dan Tracking.

\section{Kajian Literatur}

\section{A. Kualitas Informasi}

Informasi (Information) adalah data yang telah di olah menjadi suatu bentuk bagi penerima dan mempunyai nilai yang nyata atau dapat di rasakan manfaatnya dalam keputusan-keputusan yang akan datang. Informasi merupakan sumberdata vital bagi kelangsungan organisasi bisnis dan termasuk bagian terpenting dalam membangun kepercayaan terhadap konsumennya.

Kualitas informasi sebagai suatu fungsi menyangkut nilai dari keluaran yang dihasilkan oleh suatu sistem yang dirasakan oleh pengguna. Suatu karakteristik dari suatu informasi demi memenuhi kebutuhan individu saat dibutuhkan. Pembuatan informasi merupakan proses menyusun, mengatur, memformat dan menyajikan informasi kepada pengguna. Indikator diperlukan karena kualitas informasi merupakan variabel yang tidak dapat diukur secara langsung [4].
B. Pengukuran Kualitas Informasi

Informasi harus memenuhi kualitas informasi (quality of information) yang ditentukan oleh beberapa faktor [5], yaitu:

1. Relevan (relevancy)

Seberapa jauh tingkat relevansi informasi tersebut terhadap kenyataan kejadian masa lalu, kejadian hari ini dan kejadian yang akan datang.

2. Akurat (accuracy)

Suatu informasi dikatakan berkualitas jika seluruh kebutuhan informasi tersebut telah tersampaikan (completeness), seluruh pesan telah benar/sesuai (correctness), serta pesan yang disampaikan sudah lengkap atau hanya sistem yang diinginkan oleh user (security).

3. Tepat waktu (timeliness)

Berbagai proses dapat diselesaikan dengan tepat waktu, laporan-laporan yang dibutuhkan dapat disampaikan tepat waktu.

4. Ekonomis (economy)

Informasi yang dihasilkan mempunyai daya jual yang tinggi, serta biaya operasional untuk menghasilkan informasi tersebut minimal, informasi tersebut juga mampu memberikan dampak yang luas terhadap laju pertumbuhan ekonomi dan teknologi informasi.

5. Efisien (efficiency)

Informasi yang berkualitas memiliki sintaks maupun kalimat yang sederhana (tidak berbelitbelit, tidak juga puitis, bahkan romantis), namun mampu memberikan makna dan hasil yang mendalam, atau bahkan menggetarkan setiap orang atau benda apapun yang menerimanya.

6. Dapat dipercaya (reliability)

Informasi tersebut berasal dari sumber yang dapat dipercaya dan telah diuji tingkat kejujurannya.

Kualitas dari suatu informasi tergantung dari 3 (tiga) hal [6] yaitu sebagai berikut:

1. Akurat (accurate)

Informasi harus akurat karena dari sumber informasi sampai ke penerima informasi mungkin banyak mengalami gangguan (noise) yang dapat mengubah atau merusak informasi tersebut.

\section{Tepat waktu (timelines)}

Informasi yang sampai ke penerima tidak boleh terlambat. Informasi yang sudah usang tidak akan mempunyai nilai lagi, karena informasi merupakan landasan didalam pengambilan keputusan. 


\section{Relevan (relevance)}

Seberapa jauh tingkat relevansi informasi tersebut terhadap kenyataan kejadian masa lalu, kejadian hari ini dan kejadian yang akan datang. Informasi yang berkualitas akan mampu menunjukan benang merah relevansi tersebut.

Indikator pengukur kualitas informasi didasarkan pada faktor-faktor [7] berikut: (1)Kepentingan (importance), (2)Kejelasan (clarity), (3)Relevan (relevance), (4)Kegunaan (usefulness).

\section{A. Teknik Sampel}

\section{Metodologi}

Teknik sampel mengambil pendekatan pengambilan sampel non-probability sampling dengan Sampling insidental. Non-probability Sampling adalah teknik sampling yang tidak memberikan kesempatan (peluang) pada setiap anggota populasi untuk dijadikan anggota sampel. Sampling Insidental adalah teknik penentuan sampel berdasarkan faktor spontanitas, artinya siapa saja yang secara tidak sengaja bertemu dengan peneliti dan sesuai dengan karakteristik (ciri-cirinya), maka orang tersebut dapat digunakan sebagai sampel (responden)[8].

Cara pengambilan sampel dengan menggunakan pendekatan sampling nonprobability dimana peneliti membatasi jumlah sampelnya. Dalam penelitian ini menggunakan rumus solvin, yaitu sebagai berikut:

$\mathrm{N}=\mathrm{N} /(1+\mathrm{Ne} 2)$

\section{Rumus 1. Slovin}

Dimana $: \mathrm{n}=$ Jumlah sampel

$\mathrm{N}=$ Jumlah Populasi

$\mathrm{E}=$ Kelonggaran pengambilan sampel,

presisi $5 \% \mathrm{~d}^{2}$

Dengan nilai $d=100 \%$ maka sampel yang didapat sebagai berikut:

$$
\begin{aligned}
& \mathrm{n}=189 /\left(1+(189)^{*}(0.05)^{\wedge} 2\right) \\
& \mathrm{n}=128.8
\end{aligned}
$$

Dapat disimpulkan bahwa penelitian ini memiliki 128.8 responden dibulatkan menjadi 129 responden $(n=129)$.

\section{B. Metode Analisis}

Metode analisis yang digunakan dalam penelitian ini adalah deskriptif, analisis deskriptif adalah analisis yang menjelaskan suatu data yang telah dikumpulkan dan diringkas pada aspekaspek penting berkaitan dengan data tersebut [9]. Analisis deskriptif dilakukan dengan menyusun tabel frekuensi distribusi untuk mengetahui apakah tingkat perolehan nilai (skor) variabel penelitian masuk ke dalam kategori: sangat setuju, setuju, ragu-ragu/kurang setuju, tidak setuju, sangat tidak setuju.

Teknik analisis yang digunakan untuk menginterprestasikan dan menganalisis data sesuai dengan analisis Deskriptif. Statistik deskriptif adalah statistik yang digunakan untuk menganalisa data dengan cara mendeskripsikan atau menggambarkan data yang telah terkumpul sebagaimana adanya tanpa bermaksud membuat kesimpulan yang berlaku untuk umum atau generalisasi [10].

Penelitian yang dilakukan pada populasi jelas akan menggunakan statistik deskriptif dalam analisisnya, tetapi bila penelitian dilakukan pada sampel, maka analisisnya dapat menggunakan statistik deskriptif maupun infensial. Statistik deskriptif dapat digunakan bila peneliti hanya ingin mendeskripsikan data sampel, dan tidak ingin membuat kesimpulan yang berlaku untuk populasi dimana sampel diambil.

Selanjutnya hasil perhitungan perbandingan antara skor aktual dengan skor ideal dikontribusikan dengan tabel 1 berikut ini: Dalam pengukuran hipotesis penelitian ini, rumus yang digunakan untuk megukur rentang skala adalah:

$\mathrm{RK}=\mathrm{n}(\mathrm{m}-1) / \mathrm{m}$

Keterangan:

Rumus 2. Rentang Skala

$\mathrm{n}=$ Jumlah sampel

$\mathrm{m}=$ Jumlah alternatif item

Berdasarkan rumus diatas maka diperoleh jumlah rentang skala sebagai berikut:

$\mathrm{RK}=(129(5-1)) / 5$

$\mathrm{RK}=103.2$

Jadi kelas rentang skala pada penelitian ini adalah:

Tabel 1. Rentang Skala

\begin{tabular}{|l|l|l|}
\hline No & Rentang Skala & Kriteria \\
\hline 1 & $129-232,2$ & Sangat tidak baik \\
\hline 2 & $232,3-335,4$ & Tidak baik \\
\hline 3 & $335,5-438,6$ & Netral \\
\hline 4 & $438,7-541,8$ & Baik \\
\hline 5 & $541,9-645$ & Sangat Baik \\
\hline
\end{tabular}




\section{Pembahasan}

A. Analisis Deskriptif

Analisis Deskriptif seperti yang telah diterangkan pada Bab Metodologi Penulisan mengungkapkan bahwa analisis deskriptif dilakukan untuk mengetahui tingkah laku data yang diperoleh dan juga digunakan untuk mengetahui gambaran masing-masing variabel.

Hasil pengelolahan data dengan analisa deskriptif untuk masing-masing variabel yaitu Kualitas informasiakan dibahas satu persatu secara detail dan terperinci.

Variabel Kualitas Informasi memiliki 4 buah indikator yang dibuat penulis menjadi 4 butir pernyataan dalam kuesioner dengan menggunakan skala Likert dengan pembobotan, Sangat Setuju $=5$, Setuju $=4$, Netral $=3$, Tidak Setuju $=2$, Sangat-sangat Tidak Setuju $=1$. Untuk distribusi dan perhitungan skor dari olahan data, akan dijelaskan dalam tabel yang nantinya juga akan diperoleh presentase masingmasing butir pernyataan ataupun keseluruhan variabel yang pada akhirnya dapat berfungsi menjawab hipotesa deskriptif penelitian.

Tabel 2. Deskriptif Variabel Kualitas Informasi.

Descriptive Statistics
\begin{tabular}{|l|l|l|l|l|l|l|}
\hline & & & & & & Std. \\
& N & Min & Max & Sum & Mean & Deviation \\
\hline KI1 & 129 & 4.00 & 5.00 & 598.00 & 4.6357 & .48312 \\
KI2 & 129 & 3.00 & 5.00 & 598.00 & 4.6357 & .51445 \\
KI3 & 129 & 3.00 & 5.00 & 579.00 & 4.4884 & .56064 \\
KI4 & 129 & 3.00 & 5.00 & 591.00 & 4.5814 & .51078 \\
Valid N & 129 & & & & & \\
(listwise) & & & & & & \\
\hline
\end{tabular}

Berdasarkan tabel 2. diatas adalah hasil olahan data deskriptif, maka disajikan dalam tabel yang lebih detail bahwa Kualitas Informasi mempunyai skor masing-masing dari setiap pernyataan sebagai berikut:

\section{Kepentingan (importance)}

Berdasarkan data yang didapat mengenai indikator informasi dilihat dari kebutuhan atau kepentingan(importance) dari Sistem Informasi Trace dan Tracking pada PT JNE Expression Across Nations dapat dilihat dari tabel berikut:

Tabel 3. Perhitungan Skor Informasi Kepentingan (Importance)

\begin{tabular}{|c|c|c|c|c|c|c|c|c|c|}
\hline \multirow[t]{2}{*}{ No } & \multirow[t]{2}{*}{ Pernyataan } & \multirow{2}{*}{\begin{tabular}{|l|} 
SS \\
5 \\
\end{tabular}} & \multirow{2}{*}{$\mathrm{S}$} & \multirow{2}{*}{\begin{tabular}{|l}
$\mathrm{N}$ \\
3 \\
\end{tabular}} & \multirow{2}{*}{$\begin{array}{l}\text { TS } \\
2 \\
\end{array}$} & \multirow{2}{*}{$\begin{array}{l}\text { STS } \\
1 \\
\end{array}$} & \multirow{2}{*}{$\begin{array}{l}\text { Skor } \\
\text { Jml }\end{array}$} & \multicolumn{2}{|c|}{\begin{tabular}{|l|} 
Skor \\
pernyataan
\end{tabular}} \\
\hline & & & & & & & & Total & $\%$ \\
\hline 1 & $\begin{array}{l}\text { Informasi } \\
\text { sesuai } \\
\text { kebutuhan }\end{array}$ & 82 & 47 & 0 & 0 & 0 & 129 & 598 & $25,3 \%$ \\
\hline
\end{tabular}

Dari tabel 3. dapat dilihat bahwa indikator informasi dilihat dari kebutuhan atau kepentingan(importance) dari Sistem Informasi Trace dan Tracking pada PT JNE Expression Across Nations menunjukkan presentase sebesar $25.3 \%$ atau dengan skor keseluruhan sebanyak 598 yang jika disimpulkan berada pada rentang kelas "Sangat Baik" (541,9 - 645).

\section{Kejelasan (clarity)}

Berdasarkan data yang didapat mengenai indikator informasi dilihat dari Kejelasan (clarity) dari Sistem Informasi Trace dan Tracking pada PT JNE Expression Across Nations dapat dilihat dari tabel berikut:

Tabel 4. Perhitungan Skor Informasi Kejelasan (clarity).

\begin{tabular}{|l|l|l|l|l|l|l|l|l|l|}
\hline \multirow{2}{*}{ NO } & \multirow{2}{*}{ Pernyataan } & SS & S & N & TS & STS & Skor & \multicolumn{2}{|l|}{$\begin{array}{l}\text { Skor } \\
\text { pernyataan }\end{array}$} \\
\cline { 2 - 9 } & 5 & 4 & 3 & 2 & 1 & Jml & Total & \% \\
\hline & $\begin{array}{l}\text { Informasi } \\
\text { yang } \\
\text { diberikan } \\
\text { jelas }\end{array}$ & 84 & 43 & 2 & 0 & 0 & 129 & 598 & $25,3 \%$ \\
\hline
\end{tabular}

Dari tabel 4. dapat dilihat bahwa rata-rata indikator informasi dilihat dari Kejelasan (clarity) dari Sistem Informasi Trace dan Tracking pada PT JNE Expression Across Nations menunjukkan presentase sebesar $25.3 \%$ atau dengan skor keseluruhan sebanyak 598 yang jika disimpulkan berada pada rentang kelas "Sangat Baik" (541,9 - 645).

\section{Relevan (relevance)}

Berdasarkan data yang didapat mengenai indikator informasi dilihat dari Relevan (relevance) dari Sistem Informasi Trace dan Tracking pada PT JNE Expression Across Nations dapat dilihat dari tabel berikut:

Tabel 5. Perhitungan Skor Informasi Relevan (relevance).

\begin{tabular}{|l|l|l|l|l|l|l|l|l|l|}
\hline \multirow{2}{*}{ NO } & Pernyataan & SS & S & N & TS & STS & Skor & \multicolumn{2}{|l|}{$\begin{array}{l}\text { Skor } \\
\text { pernyataan }\end{array}$} \\
\cline { 2 - 10 } & 5 & 4 & 3 & 2 & 1 & Jml & Total & $\%$ \\
\hline & $\begin{array}{l}\text { Informasi } \\
\text { yang } \\
\text { diberikan } \\
\text { relevan }\end{array}$ & 67 & 58 & 4 & 0 & 0 & 129 & 579 & $24,5 \%$ \\
\hline
\end{tabular}

Dari tabel 5. dapat dilihat bahwa rata-rata indikator informasi dilihat dari Relevan (relevance) dari Sistem Informasi Trace dan Tracking pada PT JNE Expression Across Nations menunjukkan presentase sebesar $24.5 \%$ atau dengan skor keseluruhan sebanyak 579 yang 
jika disimpulkan berada pada rentang kelas "Sangat Baik" (541,9 - 645).

\section{Kegunaan (usefulness)}

Berdasarkan data yang didapat mengenai indikator informasi dilihat dari Kegunaan (usefulness) dari Sistem Informasi Trace dan Tracking pada PT JNE Expression Across Nations dapat dilihat dari tabel berikut:

Tabel 6. Perhitungan Skor Informasi Kegunaan

\begin{tabular}{|l|l|l|l|l|l|l|l|l|l|}
\multicolumn{10}{c|}{ (usefulness). } \\
\hline \multirow{2}{*}{ NO } & Pernyataan & SS & S & N & TS & STS & Skor & \multicolumn{2}{|l|}{$\begin{array}{l}\text { Skor } \\
\text { pernyataan }\end{array}$} \\
\cline { 2 - 10 } & 5 & 4 & 3 & 2 & 1 & Jml & Total & $\%$ \\
\hline \multirow{2}{*}{1} & $\begin{array}{l}\text { Informasi } \\
\text { sesuai } \\
\text { kegunaan }\end{array}$ & 76 & 52 & 1 & 0 & 0 & 129 & 591 & $25 \%$ \\
\hline
\end{tabular}

Dari tabel 6. dapat dilihat bahwa rata-rata indikator informasi dilihat dari Kegunaan (usefulness) dari Sistem Informasi Trace dan Tracking pada PT JNE Expression Across Nations menunjukkan presentase sebesar 25\% atau dengan skor keseluruhan sebanyak 591 yang jika disimpulkan berada pada rentang kelas "Sangat Baik" (541,9 - 645).

Adapun secara keseluruhan mengukur ketepatan kualitas informasi pada sistem tracer dan tracking jasa kurir (studi kasus jne batam) dapat dijelaskan pada tabel berikut:

Tabel 7. Perhitungan Skor Variabel Kualitas Informasi.

\begin{tabular}{|l|l|l|l|l|l|l|l|l|l|}
\hline \multirow{2}{*}{ No } & Pernyataan & SS & S & N & TS & STS & Skor & \multicolumn{2}{|l|}{$\begin{array}{l}\text { Skor } \\
\text { pernyataan }\end{array}$} \\
\cline { 2 - 9 } 1 & 5 & 4 & 3 & 2 & 1 & Jml & Total & \% \\
\hline & $\begin{array}{l}\text { Informasi } \\
\text { sesuai } \\
\text { kebutuhan }\end{array}$ & 82 & 47 & 0 & 0 & 0 & 129 & 598 & $25,3 \%$ \\
\hline & $\begin{array}{l}\text { Informasi } \\
\text { yang } \\
\text { diberikan } \\
\text { jelas }\end{array}$ & 84 & 43 & 2 & 0 & 0 & 129 & 598 & $25,3 \%$ \\
\hline & $\begin{array}{l}\text { Informasi } \\
\text { yang } \\
\text { diberikan } \\
\text { relevan }\end{array}$ & 67 & 58 & 4 & 0 & 0 & 129 & 579 & $24,5 \%$ \\
\hline & $\begin{array}{l}\text { Informasi } \\
\text { sesuai } \\
\text { kegunaan }\end{array}$ & 76 & 52 & 1 & 0 & 0 & 129 & 591 & $25 \%$ \\
\hline & Jumlah & 309 & 200 & 7 & 0 & 0 & 516 & 2366 & $100 \%$ \\
\hline & $\%$ & $60 \%$ & $38,7 \%$ & $1,3 \%$ & $0 \%$ & $0 \%$ & $100 \%$ & & \\
\hline & Rata-rata variabel \\
\hline
\end{tabular}

Dari tabel 7. dapat dilihat bahwa rata-rata keseluruhan kualitas informasi dari Sistem Informasi Trace dan Tracking pada PT JNE Expression Across Nations menunjukkan menunjukkan presentase sebesar $25 \%$ atau dengan skor keseluruhan sebanyak 591,5 yang jika disimpulkan berada pada rentang kelas "Sangat Baik" (541,9 - 645).

Apabila ditinjau dari grafik nilai dari masing-masing indikator mempunyai nilai yang http://ejournal.upbatam.ac.id/index.php/cbis saling berdekatan atau hampir sama. Baik dari indikator kepentingan (importance), kejelasan (clarity), relevan (relevance), kegunaan (usefulness) bernilai sangat baik. Berikut grafik perbedaan total skor masing-masing indikator:

\section{Total Skor}

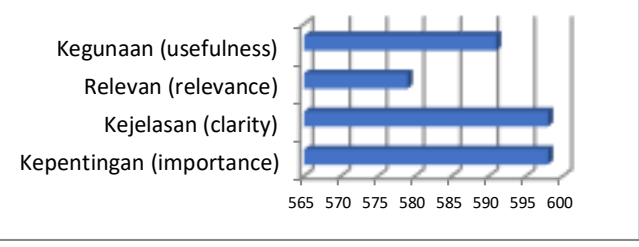

Gambar 2. Total Skor Pengukuran

B. Pembahasan

Berdasarkan hasil analisis deskriptif maka dapat di jelasakan setiap variabel sebagai berikut:

1. Kepentingan (importance)

Berdasarkan data yang didapat mengenai indikator informasi dilihat dari kebutuhan atau kepentingan(importance) dari Sistem Informasi Trace dan Tracking pada PT JNE Expression Across Nations menunjukkan presentase sebesar $25.3 \%$ atau dengan skor keseluruhan sebanyak 598 yang jika disimpulkan berada pada rentang kelas "Sangat Baik" (541,9 - 645).

\section{Kejelasan (clarity)}

Berdasarkan data yang didapat mengenai indikator informasi dilihat dari Kejelasan (clarity) dari Sistem Informasi Trace dan Tracking pada PT JNE Expression Across Nations menunjukkan presentase sebesar $25.3 \%$ atau dengan skor keseluruhan sebanyak 598 yang jika disimpulkan berada pada rentang kelas "Sangat Baik" (541,9 - 645).

\section{Relevan (relevance)}

Berdasarkan data yang didapat mengenai indikator informasi dilihat dari Relevan (relevance) dari Sistem Informasi Trace dan Tracking pada PT JNE Expression Across Nations menunjukkan presentase sebesar $24.5 \%$ atau dengan skor keseluruhan sebanyak 579 yang jika disimpulkan berada pada rentang kelas "Sangat Baik" (541,9 - 645). 


\section{Kegunaan (usefulness)}

Berdasarkan data yang didapat mengenai indikator informasi dilihat dari Kegunaan (usefulness) dari Sistem Informasi Trace dan Tracking pada PT JNE Expression Across Nations menunjukkan presentase sebesar 25\% atau dengan skor keseluruhan sebanyak 591 yang jika disimpulkan berada pada rentang kelas "Sangat Baik" (541,9 - 645).

\section{Kesimpulan}

Berdasarkan hasil pengujian dapat ditarik beberapa kesimpulan dari penelitian ini adalah sebagai berikut: (1)Informasi dilihat dari kebutuhan atau kepentingan (importance) dari Sistem Informasi Trace dan Tracking menunjukkan sangat baik karena memang konsumen membutuhkan status dari pengiriman barang. (2)Informasi dilihat dari Kejelasan (clarity) keterangan proses pengiriman menunjukkan sangat baik. (3)Informasi dilihat dari Relevan (relevance) dari Sistem Informasi Trace dan Tracking pada PT JNE Expression Across Nations menunjukkan sangat baik terlihat dari terdapat keterangan waktu pengiriman. (4)Informasi dilihat dari Kegunaan (usefulness) sistem sangat dibutuhkan baik pihak pengirim maupun penerima.

\section{Ucapan Terima Kasih}

Terimakasih kepada LPPM Universitas Putera Batam sebagai Lembaga yang membantu pengembangan penelitian.

\section{Daftar Pustaka}

[1] Hidayat, Taufiq. (2015). Pengaruh marketing public relation terhadap Loyalitas pelanggan pada pt. Jalur nugraha Ekakurir (jne) bandung. Jurnal Ekonomi, Bisnis \& Entrepreneurship. Vol. 9, No. 2, Oktober 2015, Hal. 102-115. ISSN 24432121

[2] Nadeak, Lastri. (2014). Implementasi metode simpleks untuk maksimasi Pendistribusian barang kiriman (Studi Kasus : PT. Tiki Jalur Nugraha Eka Kurier Medan). Pelita Informatika Budi Darma, Volume: VIII, Nomor: 3, Desember 2014 ISSN : 2301-9425.
[3] Barnes, J. S. (2013). An Integrative Approach to the Assessment of ECommerce Quality. Journal of Electronic Commerce Research, VOL. 3, NO. 3, 2012.

[4] Dewi, Sang Ayu Nyoman Trisna dan AANB Dwiranda, (2013). Pengaruh Dukungan Manajemen Puncak, Kualitas Sistem, Kualitas Informasi, Pengguna Aktual dan Kepuasan Pengguna Terhadap Implementasi Sistem Informasi Keuangan Daerah Di Kota Denpasar, E-jurnal Akuntansi Universitas Udayana. 4 (1): 196214.

[5] Ladjamuddin, AL. Bahra Bin. (2010). Analisis dan Desain Sistem Informasi. Edisi Revisi. Graha Ilmu. Yogyakarta.

[6] Sutabri, Tata. (2012). Analisis Sistem Informasi. Edisi Pertama. Andi. Yogyakarta.

[7] Jogiyanto (2008) Analisis \& Desain Sistem Informasi: Pendekatan Terstruktur, Teori, dan Aplikasi Bisnis, Edisi Ketiga. Andi. Yogyakarta.

[8] Sugiyono. (2013). Metode Penelitian Pendekatan Kuantitatif kualitatif Dan R \& $\mathrm{D}$, cetakan kesembilan belas. Bandung: Alfa Beta.

[9] Wibowo, Agung Edy (2012). Aplikasi Praktis SPSS dalam Penelitian. Gaya Media. Yogyakarta.

[10] Sugiyono (2012).Metode Penelitian Kuantitatif Kualitatif dan R. 